\title{
Job Satisfaction and Intention of Primary Healthcare Workers to Leave: A Cross-Sectional Study in a Local Government Area in Lagos, Nigeria
}

\author{
Adeyinka Adeniran ${ }^{1}$, Esther O. Oluwole ${ }^{2} \&$ Omobola Y. Ojo ${ }^{3}$ \\ ${ }^{1}$ Department of Community Health and Primary Health Care, Lagos State College of Medicine, Ikeja, Lagos, \\ Nigeria \\ ${ }^{2}$ Department of Community Health and Primary Care, College of Medicine, University of Lagos, Lagos, Nigeria \\ ${ }^{3}$ Department of Community Medicine and Primary Care, Federal Medical Center, Abeokuta, Nigeria \\ Correspondence: Esther O. Oluwole, Department of Community Health and Primary Care, College of Medicine, \\ University of Lagos, Lagos, Nigeria.
}

\author{
Received: October 17, 2020 Accepted: February 25, 2021 Online Published: March 29, 2021 \\ doi:10.5539/gjhs.v13n4p138 URL: https://doi.org/10.5539/gjhs.v13n5p138
}

\begin{abstract}
The increased intention of healthcare workers to leave the health sector is one of the many negative impacts of job dissatisfaction and poor working conditions among healthcare workers in Nigeria. This study assessed the level of job satisfaction and the intention of leaving the country or medical practice among primary healthcare workers in Lagos, Nigeria. The study was a descriptive cross-sectional among 235 respondents, selected using a multistage sampling method. An adapted self-administered questionnaire from the Minnesota questionnaire short form and the Job Description Index (JDI) was used for data collection. Data were analyzed with Statistical Package for Social Sciences (SPSS) version 22.0. Descriptive statistics were performed while Chi-square was used to determine the association between categorical variables and the level of significance was set at $p<0.05$. About half $(50.6 \%)$ of the healthcare workers were satisfied with their jobs. Highest score 37.00 (32-40) for job satisfaction was found in the domain of management process; while the lowest score 16.00 (13-20) was found in the salary domain. The majority of the healthcare workers $201(85.5 \%)$ had the intention of leaving Nigeria for a better opportunity abroad. Healthcare workers were satisfied with the management process but dissatisfied with pay. Targeted interventions to improve the morale of healthcare workers at the primary healthcare level is recommended.
\end{abstract}

Keywords: Healthcare workers, job satisfaction, intention to leave, primary healthcare centres, Lagos, Nigeria

\section{Introduction}

Healthcare professionals constitute one of the most important factors in the component of the health system as a human resource for health. Job satisfaction is defined as the pleasurable emotional state resulting from the appraisal of one's job (Chaudhury, 2004; Thompson, 2012). Job satisfaction refers to the degree to which an individual feel positive or negative about his or her job. Health workers' dissatisfaction with jobs poses significant public health implications, as this will most likely adversely affect the clinical management of patients (Pathman et al., 2002). Job satisfaction and morale of medical practitioners is of concern as satisfied healthcare workers usually perform well and have reduced absenteeism (Zuger, 2004). Continuous and effective productivity of healthcare workers has been linked to job satisfaction. Hence, satisfied hospital staffs have been observed to be more contented and productive while those who were not happy with their job are likely to encounter job stress, occupational burnout and stress-related physical and psychological health disorders (Pindar, Wakil, \& Coker, 2015)

Job satisfaction as a constitutional concept contains the features of the job and the job-related environment from five aspects which consists of the supervisors, the jobs, the work colleagues, the compensation, and the promotion opportunities (Zhu, 2013). Job satisfaction has been measured based on the extrinsic and intrinsic factors. The extrinsic factors include pay, company policy, interpersonal relations, working conditions, status and job security while intrinsic factors are; achievements, recognition, the work itself, responsibility, advancement, and possibility of growth in the job (Okaro \& Eze, 2010). Hence, three categories of the components of job satisfaction have been described as; the job, the people involved (colleagues, superiors, subordinates) and policies of the organization 
(retirement, promotion, training) (Adeoye, 2014).

The increased intention of healthcare workers to leave the health sector is one of the many negative impacts of job dissatisfaction among healthcare workers, which results in the shortage of health workers and increased work pressure on the remaining few leading to poor health care delivery, declining health indices, incessant strike actions, and impairment of the psychological health of the workers (Liu \& Wang, 2010). In sub-Sahara Africa, the constant emigration of trained medical personnel is on the rise as a result of dissatisfaction with either the extrinsic or/and intrinsic factors of the job (Sieleunou, 2011). A major factor responsible for the poor health indices and disparities in the health outcomes in Low Middle-Income Countries (LMIC) is the mass emigration of healthcare workers to countries with better health indices (Janus, Amelung, \& Gaitanides, 2007). In Nigeria, incessant strike actions have also been linked to job dissatisfaction (Akinyemi \& Atilola, 2013). Burnout has been found to occurs with increasing exposure to job stressors resulting from inconsistency and mismatch between the job and healthcare workers (Amiri et al., 2016; Kabir et al., 2016). Other negative results of job dissatisfactions experienced by health workers include exhaustion, frustration, anger, and negative attitudes towards work and patients (Bawakid et al., 2017). The role of occupation in the dynamics of health and diseases has long been recognized. Workers who are satisfied with their work are known to be healthier than those who do not (Ofili, Asuzu, \& Isah, 2004). There is a paucity of data about job satisfaction among primary health workers in Lagos, Nigeria. Lagos is a megacity with an increasing healthcare and workforce demands, hence the need for this study which determined the level of job satisfaction, factors affecting job satisfaction and intentions to leave job among healthcare workers in selected primary health facilities in Alimosho Local Government Area (LGA), Lagos, Nigeria.

\section{Methods}

\subsection{Study Setting}

Alimosho is one of the twenty local government area (LGA) in Lagos State, Nigeria, established in 1991. It is an urban and the largest LGA in Nigeria with about two million residents according to the 2006 population census. The LGA has five divisions into Local Community Development Areas (LCDA) namely Mosan Okunola, Ikotun/Igando, Egbe/Idimu, Ayobo/Ipaja and Agbado/Oke-Odo.

\subsection{Study Design and Population}

The study was a descriptive cross-sectional among healthcare workers in primary health care centres in Alimosho LGA. Only healthcare workers on permanent employment with the Lagos State Health Service Commission including doctors, nurses, pharmacist, technicians, community health officers, community health extension workers and laboratory technologists were included in the study.

\subsection{Sample Size Determination}

Sample size was calculated using a Cochran formula $\left(n=z^{2} \mathrm{pq} / \mathrm{d}^{2}\right)$ where $\mathrm{n}$ was the estimated minimum sample size; z-level of significance at $95 \%$ confidence level (1.96); p-proportion from a previous study of 83.3\% (0.406) (Liu, $\&$ Wang, 2010) $\mathrm{q}=(1-\mathrm{p}), \mathrm{d}=$ level of precision $(0.05 \%)$. The calculated minimum sample size was 213 , which was increased to 235 to make up for non and incomplete responses.

\subsection{Sampling Technique}

Multistage sampling method was used for the study. In stage one, three of the five LCDAs were selected by random sampling by ballot, in stage 2, three PHCs were selected from the list of PHCs in each LCDA including the comprehensive health centres by simple random sampling via ballot. In each primary health centre, all eligible health workers who met the inclusion criteria were recruited until the sample size was attained.

\subsection{Data Collection Tool}

An adapted self-administered questionnaire from the Minnesota questionnaire short form and the Job Description Index (JDI) (Measuring Job Satisfaction - Tools, Scales, Methods, (https://iedunote.com/measuring-job-satisfaction) was used for the study. It is a psychometric and most popular tool that measures job satisfaction. The JDI is based on subscales as a present job; present pay; promotion; supervision and relationship with the co-workers. The questionnaire was divided into six sections; section A consisted of socio-demographic characteristics of the respondent, section B-E was made up of questions on factors affecting job satisfaction and section $\mathrm{F}$, had questions on intentions of the health workers to leave the job.

\subsection{Data Analysis}

Data were analyzed with Statistical Package for Social Sciences (SPSS) version 22.0. Twenty-seven questions 
were used to assess job satisfaction, each question had five Likert scale items; very satisfied (5), satisfied (4), neutral (3), disagree (2) and very disagree (1). Responses were scored based on the median (IQR). Scores below and above the median (IQR)were categorized as unsatisfied and satisfied respectively. Categorical variables were presented as percentages or proportions while continuous variables were presented as mean \pm standard deviation (SD). Chi-square was used to determine the association between categorical variables. Level of significance was set at $\mathrm{p}<0.05$.

\subsection{Ethical Consideration}

Clearance was gotten from the Department of Community Health and Primary Healthcare, Lagos State University College of Medicine and the office of the Medical Officer of Health at the Alimosho LGA to carry out this study. Informed consent was verbally obtained from each respondent with the assurance of confidentiality of the information and their right to withdraw from the study at any point in time. The participants were made to understand that involvement was voluntary.

\section{Results}

Table 1 shows the socio-demographic characteristics of respondents. The mean $\pm \mathrm{SD}$ age of respondents was $37.25 \pm 9.73$. Most of the respondents were female (66.4\%), married (75.7\%) and have practised for less than 10 years $(55.7 \%)$ with a mean $\pm \mathrm{SD}$ of the practice of $10.25 \pm 8.4$. Most $(31.9 \%)$ were nurses by profession.

Table 1. Socio-demographics characteristics of respondents

\begin{tabular}{lcc}
\hline Variable & Frequency $\mathbf{n = 2 3 5}$ & Percentage (100\%) \\
\hline Age (years) & 58 & 24.7 \\
$<30$ & 89 & 37.9 \\
$30-39$ & 51 & 21.7 \\
$40-49$ & 37 & 15.7 \\
$\geq 50$ & & \\
Mean age $=37.25 \pm 9.73$ & & \\
\hline Sex & 79 & 33.6 \\
Male & 156 & 66.4 \\
Female & & \\
\hline Marital status & 49 & 20.9 \\
Single & 178 & 75.7 \\
Married & 5 & 2.1 \\
Divorced & 3 & 1.3 \\
Widowed & & 55.7 \\
\hline Year of practicing (years) & 131 & 24.7 \\
$<10$ & 58 & 8.5 \\
$10-15$ & 20 & 11.1 \\
$16-21$ & 26 & 37.0 \\
$\geq 22$ & & 3.0 \\
Mean= $10.25 \pm 8.42$ & 10 & 4.3 \\
\hline Duration in current job (years) & & \\
$<5$ & & \\
$5-10$ & & \\
$11-16$ & & \\
$\geq 17$ & & \\
Mean=5.11 4.50 & & \\
\hline & & \\
\hline
\end{tabular}




\begin{tabular}{lll}
\hline Highest level of education & & \\
OND & 61 & 26.0 \\
HND & 81 & 34.5 \\
BSC & 68 & 28.9 \\
MBBS & 25 & 10.6 \\
\hline Profession & & \\
Medical doctor & 25 & 10.6 \\
CHO/CHEW & 72 & 30.6 \\
Pharmacist/technician & 34 & 14.5 \\
Nurse & 75 & 31.9 \\
Medical laboratory technologist & 29 & 12.3 \\
\hline
\end{tabular}

Table 2 shows the respondent's job satisfaction according to different domains of the scale. About half (50.2\%) of the respondents were satisfied with job security, while $61.3 \%$ were satisfied with opportunities for advancement, less than half (48.5\%) were satisfied with support for additional training and education, $(47.6 \%)$ were satisfied with hours of work, and (48.1\%) were satisfied with recognition for work. About $49 \%$ were satisfied with the rate of promotion and delegation of duties. About half (52.8\%) of the respondents were satisfied with the physical working condition, $48.5 \%$ were satisfied with physical surroundings, $35.7 \%$ were satisfied with the necessary equipment, $34.5 \%$ were satisfied with the availability of PPE while $46.0 \%$ were satisfied with the methods of waste disposal. Above half (59.1\%) of the respondents were satisfied with the spirit of cooperation, most (64.3\%) were satisfied with coworker getting along with each other, About $60 \%$ were satisfied with the relationship with the supervisor. Less than half were satisfied with the relationship with subordinates $(46.8 \%)$, while $58.3 \%$ were satisfied with the commitment of colleagues to work and $52.8 \%$ were satisfied with the working relationship. Few $(36.2 \%)$ of the respondents were satisfied with the salary, while $31.1 \%$ were satisfied with the amount of pay for work done, $37.2 \%$ were satisfied with the comparison of pay to that for a similar position in other health facilities, $51.1 \%$ were satisfied with the benefits of the job and few (30.2\%) of the respondents were dissatisfied with salary increment.

Table 2. Respondent's job satisfaction according to different domains of the scale

\begin{tabular}{|c|c|c|c|c|c|}
\hline Variable & VS. n (\%) & S. n (\%) & N. n (\%) & D. n (\%) & VD. n (\%) \\
\hline \multicolumn{6}{|c|}{ Job satisfaction concerning management duties } \\
\hline Job security & $50(21.4)$ & $118(50.2)$ & $41(17.4)$ & $17(7.2)$ & $9(3.8)$ \\
\hline Opportunities for advancement & $27(11.5)$ & $144(61.3)$ & $36(15.3)$ & $24(10.2)$ & $4(1.70)$ \\
\hline $\begin{array}{l}\text { Support for additional training and } \\
\text { education }\end{array}$ & $34(14.5)$ & $114(48.5)$ & $56(23.8)$ & $30(12.8)$ & $1(0.4)$ \\
\hline Hours of work & $28(10.7)$ & $11(47.6)$ & $57(24.5)$ & $38(16.3)$ & $2(0.9)$ \\
\hline Recognition for work & $46(19.6)$ & $113(48.1)$ & $58(24.7)$ & $18(7.7)$ & $0(0.0)$ \\
\hline Autonomy & $16(6.8)$ & $110(46.8)$ & $97(41.3)$ & $11(4.7)$ & $1(0.4)$ \\
\hline Employee handling & $35(14.9)$ & $111(47.2)$ & $70(29.8)$ & $16(6.8)$ & $3(1.3)$ \\
\hline $\begin{array}{l}\text { Competence of supervisor in decision } \\
\text { making }\end{array}$ & $50(21.3)$ & $94(40.0)$ & $74(31.5)$ & $16(6.8)$ & $1(0.4)$ \\
\hline Rate of promotion & $45(19.1)$ & $115(48.9)$ & $48(20.4)$ & $23(9.8)$ & $4(1.7)$ \\
\hline Delegation of duties & $33(14.0)$ & $117(49.8)$ & $63(26.8)$ & $18(7.7)$ & $4(1.7)$ \\
\hline Median score (IQR) = & $37.00(32-40)$ & & & & \\
\hline
\end{tabular}




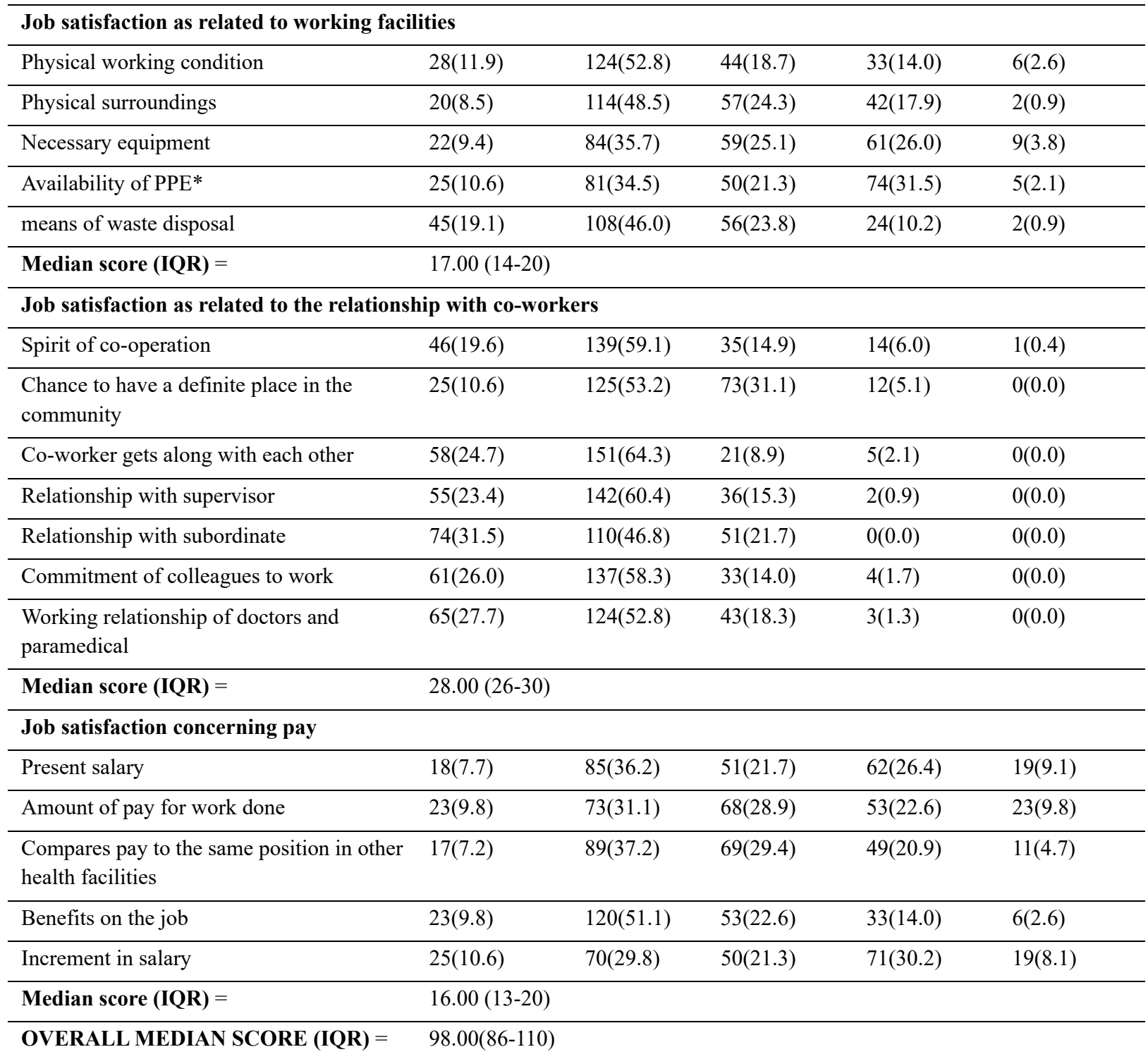

*VS (Very satisfied), S(satisfied), N(neutral), D(Disagree), VD (very disagree)

\section{Overall job satisfaction}

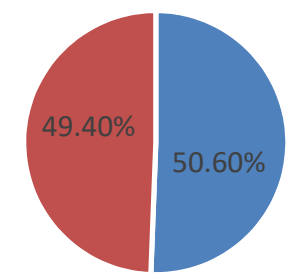

- Satisfied - Unsatisfied

Figure 1. About half $119(50.6 \%)$ of the respondents were satisfied with their job.

Table 3 shows the respondents' intention to leave the job. Majority of respondents $201(85.5 \%)$ had the intention of leaving Nigeria for a better opportunity abroad. 
Table 3. Respondent's intention to leave job

\begin{tabular}{lcc}
\hline Variable & Frequency $\mathbf{n = 2 5 3}$ & Percentage $\mathbf{\%}$ \\
\hline Ever thought of leaving the health sector & 50 & 21.3 \\
Yes & 185 & 78.7 \\
No & & \\
\hline Intentions of leaving your current organization & 52 & 22.1 \\
Yes & 183 & 77.9 \\
No & & \\
\hline Intentions of leaving Nigeria for abroad & 201 & 85.5 \\
Yes & 34 & 14.5 \\
No & 34 \\
\hline
\end{tabular}

Table 4 shows no statistically significant association between the respondents' overall level of job satisfaction and their socio-demographic characteristics ( $p>0.05)$. Most $54(72 \%)$ of nurses and doctors $11(44 \%)$ were unsatisfied with their jobs. A statistically significant association was found between the job designation and the overall level of job satisfaction of respondents. A higher proportion of nurses $(72 \%)$ were unsatisfied with their jobs compared to others $(\mathrm{p}<0.05)$.

Table 4. Association between respondent's socio-demographic variables and overall job satisfaction

\begin{tabular}{|c|c|c|c|c|}
\hline \multirow[b]{2}{*}{ Variable } & \multicolumn{2}{|c|}{ Overall job satisfaction } & \multirow{2}{*}{$\begin{array}{l}\text { Total } \\
235(100.0 \%)\end{array}$} & \multirow[b]{2}{*}{ Test statistics } \\
\hline & $\begin{array}{l}\text { Unsatisfied } \\
116(49.4 \%)\end{array}$ & $\begin{array}{l}\text { Satisfied } \\
119(50.6 \%)\end{array}$ & & \\
\hline \multicolumn{5}{|l|}{ Age (years) } \\
\hline Less than 30 & $24(41.4)$ & $34(58.6)$ & $58(100.0)$ & \\
\hline $30-39$ & $47(52.8)$ & $42(47.2)$ & $89(100.0)$ & $\mathrm{x}^{2}=2.230$ \\
\hline $40-49$ & $25(49.0)$ & $26(51.0)$ & $51(100.0)$ & $p=0.526$ \\
\hline More than 50 & $20(54.1)$ & $17(45.9)$ & $37(100.0)$ & \\
\hline \multicolumn{5}{|l|}{ Gender } \\
\hline Female & $73(46.8)$ & $83(53.2)$ & $156(100.0)$ & $\mathrm{x}^{2}=1.223$ \\
\hline Male & $43(54.4)$ & $36(45.6)$ & $79(100.0)$ & $\mathrm{p}=0.269$ \\
\hline \multicolumn{5}{|l|}{ Marital status } \\
\hline Single & $26(53.1)$ & $23(46.9)$ & $49(100.0)$ & \\
\hline Married & $89(50.0)$ & $89(50.0)$ & $178(100.0)$ & $x^{2}=5.480$ \\
\hline Divorced & $0(0.0)$ & $5(100.0)$ & $5(100.0)$ & $\mathrm{p}=0.140$ \\
\hline Widowed & $1(33.3)$ & $2(66.7)$ & $3(100.0)$ & \\
\hline \multicolumn{5}{|c|}{ Highest level of education } \\
\hline $\mathrm{BSC}$ & $40(58.8)$ & $28(41.2)$ & $68(100.0)$ & \\
\hline HND & $38(46.9)$ & $43(53.1)$ & $81(100.0)$ & $x^{2}=3.552$ \\
\hline MBBS & $11(44.0)$ & $14(56.0)$ & $25(100.0)$ & $\mathrm{p}=0.314$ \\
\hline OND & $27(44.3)$ & $34(55.7)$ & $61(100.0)$ & \\
\hline \multicolumn{5}{|c|}{ Duration of years of practice } \\
\hline$<10$ & $66(50.4)$ & $65(49.6)$ & 131(100.0) & $x^{2}=4.889$ \\
\hline $10-15$ & $25(43.1)$ & $33(56.9)$ & $58(100.0)$ & $\mathrm{p}=0.180$ \\
\hline $16-21$ & $14(70.0)$ & $6(30.0)$ & $20(100.0)$ & \\
\hline
\end{tabular}




\begin{tabular}{lllll}
\hline$\geq 22$ & $11(42.3)$ & $15(57.7)$ & $26(100.0)$ & \\
\hline Duration in current job (years) & & & & \\
$<5$ & $71(54.2)$ & $60(45.8)$ & $131(100.0)$ & \\
$5-10$ & $41(47.1)$ & $46(52.9)$ & $87(100.0)$ & $\mathrm{x}^{2}=6.059$ \\
$11-16$ & $2(28.6)$ & $5(71.4)$ & $7(100.0)$ & $\mathrm{p}=0.109$ \\
$\geq 17$ & $2(20.0)$ & $8(80.0)$ & $10(100.0)$ & \\
\hline Profession & & & & \\
CHO/CHEW & $29(40.3)$ & $43(59.7)$ & $72(100.0)$ & \\
Medical Doctors & $11(44.0)$ & $14(56.0)$ & $25(100.0)$ & $\mathrm{x}^{2}=23.302$ \\
Nurses & $54(72.0)$ & $21(28.0)$ & $75(100.0)$ & $\mathrm{p}=0.000$ \\
Pharmacists & $12(35.3)$ & $22(64.7)$ & $34(100.0)$ & \\
Technicians & $10(34.5)$ & $19(65.5)$ & $29(100.0)$ & \\
\hline
\end{tabular}

Table 5 shows the association between the respondents' overall level of job satisfaction and the intention to leave their jobs. Most $40(80 \%)$ of the respondents who were unsatisfied with their jobs either had the thought of leaving the health sector, or leaving their current organization $44(84.6 \%)$, or leaving Nigeria for abroad $107(53.2 \%)$. The differences observed were statistically significant $(\mathrm{p}<0.05)$.

Table 5. Association between respondent's overall job satisfaction and intention to leave

\begin{tabular}{|c|c|c|c|c|}
\hline \multirow[b]{2}{*}{ Variable } & \multicolumn{2}{|c|}{ Overall job satisfaction } & \multirow[b]{2}{*}{$\begin{array}{l}\text { Total } \\
235(100.0 \%)\end{array}$} & \multirow[b]{2}{*}{ Test statistics } \\
\hline & $\begin{array}{l}\text { Unsatisfied } \\
116(49.4 \%)\end{array}$ & $\begin{array}{l}\text { Satisfied } \\
119(50.6 \%)\end{array}$ & & \\
\hline \multicolumn{5}{|c|}{ Ever thought of leaving the health sector } \\
\hline No & $76(41.1)$ & $109(58.9)$ & $185(100.0)$ & $X^{2}=23.852$ \\
\hline Yes & $40(80.0)$ & $10(20.0)$ & $50(100.0)$ & $\mathrm{P}=\mathbf{0 . 0 0 0}$ \\
\hline \multicolumn{5}{|c|}{ Intentions of leaving the current organization } \\
\hline No & $72(39.3)$ & $111(60.7)$ & $183(100.0)$ & $X^{2}=33.202$ \\
\hline Yes & $44(84.6)$ & $8(15.4)$ & $52(100.0)$ & $\mathrm{P}=\mathbf{0 . 0 0 0}$ \\
\hline \multicolumn{5}{|c|}{ Intentions of leaving Nigeria for abroad } \\
\hline No & $9(26.5)$ & $25(73.5)$ & $34(100.0)$ & $\mathrm{X}^{2}=8.333$ \\
\hline Yes & $107(53.2)$ & $94(46.8)$ & 201(100.0) & $\mathrm{P}=\mathbf{0 . 0 0 4}$ \\
\hline
\end{tabular}

\section{Discussion}

The majority of the respondents in this study were between $30-39$ years with a mean $\pm \mathrm{SD}$ age of $37.25 \pm 9.73$ years, similar to the report of a study among resident doctors in Northern Nigeria (Yakasai \& Ugwa, 2013), nurses in Ekiti state (Ayamolowo \& Irinoye, 2013), and oral health workers in Nigeria (Ezeja et al., 2010), however, this finding differs from other studies in Nigeria which reported higher mean ages (Omolase, Seidu, \& Omolase, 2010; Kalamawei, \& Abeki, 2016). Overall, about half of the respondents (50.6\%) in this study were satisfied with their job, which is higher compared to similar studies among medical doctors in Benin, Nigeria (30\%) (Ofili, Asuzu, \& Isah, 2004), nurses in Ekiti (29.8\%), (Ayamolowo \& Irinoye, 2013) physicians in Pakistan (34\%) (Ghazali, Shah, \& Zaidi, 2007), health workers in Ethiopia (34.9\%), (Mulugeta, 2015) and a University-specialized hospital of Ethiopia (41.4\%) (Yami, Hamza, Hassen, \& Jira, 2011). On the other hand, the finding is lower when compared to some other studies in Nigeria. A study among radiographers in South-Eastern, Nigeria (56.3\%) (Okaro, \& Eze, 2010) physicians and nurses in Yenagoa, (57.5\%) (Kalamawei \& Abeki, 2016), Jos (64.8\%) (Gyang, et al, 2018), Ekiti (67.1\%), (Ayamolowo \& Irinoye, 2013), North-Eastern, (68.2\%) (Chirdan, et al, 2009), Owo, (78.5\%), (Omolase, Seidu, \& Omolase, 2010) and Kano (80.1\%), (Yakasai \& Ugwa, 2013). Likewise, a study on job 
satisfaction among clinical and non-clinical hospital staff in a teaching hospital in Lagos, Nigeria reported that the majority of respondents were satisfied with their job (Coker \& Coker, 2011). Studies in Vientiane reported 65.0\%, (Khamlub et al., 2013) and Indian (66\%) (Singh, Kaur, \& Verma, 2019) job satisfaction among study respondents. The variations in findings could be due to the fact that most of the studies which reported higher level of satisfaction were conducted among medical doctors only who were practicing in either secondary or tertiary healthcare institutions as opposed to the present study which was conducted among all cadres of healthcare providers in primary health care centres. The high level of dissatisfaction among healthcare providers in this study however, demands further assessment, as this could lead to reduced overall efficiency, effectiveness, and sustainability of the country healthcare system most especially at the primary health care level which is the closest to the people in the community.

This study revealed the highest satisfaction median (1QR) score of 37.00 [32-40] of 50 points in the job satisfaction domain in relation to management duties. This implying that respondents had a good perception of their job security, opportunities for advancement, support for additional training, recognition at work and all other management duties. This finding is similar to that of other studies (Yakasai \& Ugwa, 2013; Kalamawei \& Abeki, 2016; Jadoo et al., 2015). However, contrary to the study in Plateau, Nigeria which reported that the staff were not satisfied with management and training issues (Gyang et al., 2018). The lowest satisfaction median (1QR) score was in the domain of pay with 16.00 [13-20] of the 25 obtainable points. This relates to salary, pay for work done, pay compared to the same position in other health facilities, job benefits and salary increment, similar to the study in Plateau, Nigeria which reported that staff were not satisfied with salary issues and benefits. (Gyang et al., 2018). A study has reported that workers at Vientiane were generally satisfied with their job except for salary (Khamlub et al., 2013). A study in Ethiopia among healthcare workers at public hospitals found that the major reason for dissatisfaction among health workers was poor payment scheme, lack of training opportunity, lack of incentives, bureaucratic management style, poor performance evaluation system, and poor working conditions (Mulugeta \& Bali, 2015). Similarly, another study in Ethiopia among healthcare workers at a teaching hospital reported motivation, inadequate salary, insufficient training opportunities, and an inadequate number of human resources were responsible for their dissatisfaction (Yami et al., 2011). "Motivating factors like pay, fringe benefits and contingent rewards need to be met for an employee to be satisfied with work" (Singh, Kaur, \& Verma, 2019). Quality of services has been linked to skills, motivation, and satisfaction of healthcare workers and it has been documented about the factors affecting the satisfaction of healthcare workers that managers who devote their time to work are more likely to gain improved performance (Singh, Kaur, \& Verma, 2019).

The median (1QR) score for job satisfaction as related to working facilities was 17.00 [14-20] of 25 points. This refers to the physical working condition, physical surroundings, necessary equipment, availability of PPE and means of waste disposal, similar to a study in the South-Eastern, Nigeria which reported that respondents were mostly dissatisfied with the environmental working conditions (Okaro \& Eze, 2010). The effect of the working environment, coworkers support and team dynamics, team leader qualities, and nature of work assigned to workers has been reported by various studies as determinants of job satisfaction (Merga et al., 2018).

This study found a statistically significant association between job designation and job satisfaction, whichh is similar to a study in Zaria, Nigeria which reported a statistically significant association between categories of profession and job satisfaction (Judge, Thoresen, \& Bono, 2001). Also, this study showed that job satisfaction was higher among younger respondents of less than 30 years of age, and this differs from the report of a study in Indian which found that job satisfaction was similar across all age groups. However, other studies have reported higher satisfaction in older professionals compared to the younger ones (Carrillo-García et al., 2013; Alcaraz Mor, Vigouroux, \& Urcun, 2019). Also, female respondents were more satisfied with their job compared to males in the present study. This is similar to the finding of a Spanish study (Carrillo-García et al., 2013), but different from another study in Indian (Jadoo et al., 2015), and a survey conducted among German physicians (Behmann et al., 2012). However, a previous study reported that gender is not a strong independent predictor for job satisfaction (Keeton, Fenner, \& Johnson, 2007). The differences may be ascribed to cultural differences. In Nigeria, women comprise $47.9 \%$ of the workforce (World Health Organization, 2014).

This study found less satisfaction among nurses (28\%), similar to the study in Lagos (Coker \& Coker, 2011), and Plateau, Nigeria which reported that the nurses were least satisfied with their salaries but most satisfied with the work itself and supervision (Ofili, Asuzu, \& Isah, 2004). However, this finding is different from the higher job satisfaction scores reported among nurses in Calabar, Nigeria (82.4\%), (Samson-Akpan, Edet, \& Neji, 2015) and a study from Indian among nurses (Khamlub et al., 2013). The lower satisfaction reported by the present study may be due to the shortage of nurses in the primary health centres with resultant work stress among the few available. 
Highest job satisfaction was found among the technicians in the present study, contrary to a study in a tertiary care institute of Delhi which found technicians to be the least satisfied (Jaiswal et al., 2015). Above half (56\%) of medical doctors in the present study were satisfied with their job, similar to the study in Lagos, (Coker \& Coker, 2011) and Benin, Nigeria (Ofili, Asuzu, \& Isah, 2004) where 54\% of doctors were satisfied with their job. Another study from Ondo state, Nigeria found $46.8 \%$ and $51.3 \%$ of doctors were dissatisfied with their medical skills and research opportunities respectively (Omolase, Seidu, \& Omolase, 2010). The differences observed in the level of satisfaction may be due to the different roles assigned to the different professionals. Generally, dissatisfaction among healthcare workers has been attributed to the presence of several cadres for the same job but diverse pay scales, lack of autonomy regarding professional decisions, stagnation and in-commensurate remuneration (Jaiswal, et al., 2015; Hwara, 2009). The findings of our study showed that about two-thirds (65\%) of the pharmacists were satisfied with their job compared to other clinical staff, similar to previous study findings (Murawski \& Payakachat, 2008).

Our study showed that majority of respondents who were unsatisfied with their jobs either wanted to leave the health sector $40(80 \%)$ or leave the current organization $44(84.6 \%)$ or leave Nigeria for abroad $107(53.2)$. A study in the Eastern region of Ethiopia reported a positive relationship of high intention to leave and job satisfaction (Getie \& Betre, 2013). Another study in Southwest Ethiopian health institutions reported that more than half (59.4\%) of the healthcare professionals had intended to leave their job (Gesesew, Tebeje, \& Alemseged, 2016). The World Health Organization had reported a global concern for the shortage of human resource in health care (WHO, 2014). Unsatisfied job is one of the significant and persistent predictors of intention to leave the job and migration of healthcare workers. A significant relationship between pay, promotion opportunity, and job satisfaction has been reported and health system were encouraged to consider these to prevent brain drains (Singh, Kaur, \& Verma, 2019).

Job dissatisfaction among health workers can also be accredited to poor or lack of necessary equipment, limited office spaces, longer working hours, the uncertainty of roles, home and work stress interface, work overload, lack of autonomy, frequent night shift duties, job insecurity, limited resources, communication and interpersonal relationship problems among colleagues, perceived lack of support from hospital authority and bureaucracy (Coker \& Coker, 2011). Regular capacity building, timely medical intervention for sick staff, frequent job reward to enhance a sense of work pride and team blend among others by hospital management and other stakeholders has also been encouraged to prevent job dissatisfaction among health workers (Coker \& Coker, 2011). Job satisfaction in healthcare providers has been documented to have a direct consequence on quality, effectiveness, work efficiency and the health-care costs. Also, healthcare worker job satisfaction is directly linked with work absenteeism, human relations and organization of work. (Dragana, Arandjelovic, \& Maja, 2008).

\section{Limitations of the Study}

This study was cross-sectional and self-report, hence, there might have been biases in the answers to the questions. Also, the results may not be representative of all the healthcare workers in Lagos State.

\section{Conclusion}

The overall job satisfaction among primary healthcare workers was $50.6 \%$. Healthcare workers were not satisfied with pay and physical working condition, physical surroundings, necessary equipment, availability of PPE and waste disposal mechanism. Majority of respondents who were unsatisfied with their jobs had the intention to leave the job.

\section{Recommendations}

Targeted interventions to increase job satisfaction among primary healthcare workers by the state government and involvement of relevant stakeholders to plan and implement necessary measures at the healthcare facilities to improve the level of satisfaction and well-being of the healthcare personnels are recommended.

\section{Acknowledgements}

The authors thank all the respondents who participated in this study and the medical officers of health in charge of the facilities, as well as those who collected the data.

\section{Authors' Contributions}

AA: Conception and study design, interpretation and manuscript review.

EOO: Conception and study design, data analysis, manuscript writing and review.

OYO: Conception and manuscript review. 
All authors approved the final manuscript.

\section{Funding}

This research received no grant from any agency.

\section{Competing Interests Statement}

The researchers declare that they had no financial or personal relationship(s) which may have influenced them inappropriately in the writing of this article.

\section{References}

Adeoye, A. O. (2014). The Influence of Compensation Management on Employee's Leadership Role in Insurance Sector: Nigeria Experience. Mediterranean Journal of Social Sciences, 9(27), 342-352. https://doi.org/10.5901/mjss.2014.v5n27p342

Akinyemi, O., \& Atilola, O. (2013). Nigerian resident doctors on strike: insights from and policy implications of job satisfaction among resident doctors in a Nigerian teaching hospital. International Journal of Health Planning and Management, 28(1), e46-61. PMID: 22961749. https://doi.org/10.1002/hpm.2141

Alcaraz Mor, R., Vigouroux, A., \& Urcun, A. (2019). Quality of work life of young hospital doctors? Satisfied despite everything. Sante Publique (Paris), 31, 113. https://doi.org/10.3917/spub.191.0113

Amiri, M., Khosravi, A., Eghtesadi, A, R., Sadeghi, Z., Abedi, G., Ranjbar, M., \& Mehrabian, F. (2016). Burnout and its Influencing Factors among Primary Health Care Providers in the North East of Iran. PLoS ONE, 11(12), e0167648. https://doi.org/10.1371/journal.pone.0167648

Ayamolowo, S. J., Irinoye, O., \& Oladoyin, M. A. (2013). Job satisfaction and work environment of primary health care nurses in Ekiti State, Nigeria: An exploratory study. International Journal of caring sciences, 6(3), 531-542.

Bawakid, K., Abdulrashid, O., Mandoura, N., Shah, H. B. U, Ibrahim, A., Akkad, N. M., \& Mufti, F. (2017). Burnout of Physicians Working in Primary Health Care Centers under Ministry of Health Jeddah, Saudi Arabia. Cureus, 25, 9(11), e1877. PMID: 29383297; PMCID: PMC5784861. https://doi.org/10.7759/cureus.1877

Behmann, M., Schmiemann, G., Lingner, H., Kühne, F., Hummers-Pradier, E., \& Schneider, N. (2012). Job satisfaction among primary care physicians: results of a survey. Dtsch Arztebl Int., 109(11), 193-200. PMID: 22509226; PMCID: PMC3317533. https://doi.org/10.3238/arztebl.2012.0193

Carrillo-García, C., Solano-Ruíz Mdel, C., Martínez-Roche, M. E., \& Gómez-García, C. I. (2013). Job satisfaction among health care workers: the role of gender and age. Rev Lat Am Enfermagem, 21(6), 1314-20. English, Portuguese, Spanish. PMID: 24402344. https://doi.org/10.1590/0104-1169.3224.2369

Chaudhury, S., \& Banjerjee, A. (2004). Correlates of job satisfaction in medical officers. Medical Journal Armed Forces India, 60(4), 329-332. https://doi.org/10.1016/S0377-1237(04)80004-2

Chirdan, O. O., Akosu, J. T., Ejembi, C. L., Bassi, A. P., \& Zoakah, A. I. (2009). Perceptions of working conditions amongst health workers in state-owned facilities in northeastern Nigeria. Ann Afr Med., 8(4), 243-9. PMID: 20139547. https://doi.org/10.4103/1596-3519.59579

Coker, O. O., Coker, A. O., \& Onuoha, B. (2011). A study on job satisfaction among clinical and non-clinical hospital staff in a teaching hospital in Lagos, Nigeria. East Afr J Public Health, 8(4), 294-7. PMID: 23120939.

Dragana, N., Arandjelovic, M., Maja, N., \& Stankovic, A. (2008). Job satisfaction in health care workers. Acta Medica Medianae, 47(4). Retrieved from https://www.researchgate.net/publication $/ 26605370$ Job_satisfaction_in_health_care_workers

Ezeja, E. B., Azodo, C. C., Ehizele, A. O, Ehigiator, O., \& Oboro, H. O. (2010). Assessment of job satisfaction and working conditions of Nigerian oral health workers. International Journal of Biomedical and Health Sciences, 6(3), 143-150. Retrieved from https://www.academia.edu/15453372/Assessment_of_job_satisfaction_and_ working_conditions_of_Nigerian_oral_health_workers

Gesesew, H. A., Tebeje, B., Alemseged, F., \& Beyene, W. (2016). Health workforce acquisition, retention and turnover in southwest Ethiopian health institutions. Ethiopian Journal of health sciences, 26(4), 331-340. https://doi.org/10.4314/ejhs.v26i4.5 
Getie, G. A., Betre, E. T., \& Hareri, H. A. (2013). Assessment of Factors Affecting Turnover Intention Among Nurses Working at Governmental Health Care Institutions in East Gojjam, Amhara Region, Ethiopia. American Journal of Nursing Science, 4(3), 107-112. https://doi.org/10.11648/j.ajns.20150403.19

Ghazali, S. S., Shah, I. A., Zaidi, S. A., \& Tahir, M. H. (2007). Job satisfaction among doctors working at the teaching hospital of Bahawalpur, Pakistan. Journal of Ayub Medical College Abbottabad, 19(3), 42-5. Retrieved from https:/www.jamc.ayubmed.edu.pk/index.php/jamc/article/view/5030

Global Economy: Nigeria: Female labour force participation. The global economy.com. Retrieved August 18, 2020, from https://www.theglobaleconomy.com/Nigeria/Female_labor_force_participation/

Gyang, M. D., Dankyau, M., Gidado, S., Gyang, B. A., \& Madaki, A. J. K. (2018). Job satisfaction among healthcare workers at a district hospital in Plateau State, Nigeria. J Med Trop, 20(2), 111-116. https://doi.org/10.4103/jomt.jomt_11_18

Hwara, A. H. (2009). Motivation, job satisfaction and attitudes of nurses in the public health services of Botswana. Dissertation for Doctor of Public Administration submitted at the University of South Africa, Pretoria. Retrieved from http://hdl.handle.net/10500/3084

Jadoo, S., A. A., Aljunid, S. M., Dastan, I., Tawfeeq, R. S., Mustafa, M. A., Ganasegeran, K., et al. (2015). Job satisfaction and turnover intention among Iraqi doctors - a descriptive cross-sectional multicentre study. Hum Resour Health, 13, 21. https://doi.org/10.1186/s12960-015-0014-6

Jaiswal, P., Gadpayle, A. K., Modi, R., Padaria, R., Singhal, A., Sachdeva, S., Vajala, R., et al. (2015). Job satisfaction among hospital staff working in a Government teaching hospital in India. Medical Journal of Dr D.Y. Patil University, 8, 131-7. https://doi.org/10.4103/0975-2870.153136

Janus, K., Amelung, V. E., Gaitanides, M., \& Schwartz, F. W. (2007). German physicians "on strike"--shedding light on the roots of physician dissatisfaction. Health Policy, 82(3), 357-65. https://doi.org/10.1016/j.healthpol.2006.11.003

Judge, T. A., Thoresen, C. J., Bono, J. E., \& Patton, G. K. (2001). The job satisfaction job performance relationship: a qualitative and quantitative review. Psychol Bull, 127, 376-407. https://doi.org/10.1037/0033-2909.127.3.376

Kabir, M. J., Heidari, A., Etemad, K., Gashti, A. B., Jafari, N., et al., (2016). Job Burnout, Job Satisfaction, and Related Factors among Health Care Workers in Golestan Province, Iran. Electron Physician, 20, 8(9), 2924-2930. PMID: 27790345; PMCID: PMC5074751. https://doi.org/10.19082/2924

Kalamawei, I., Abeki, S., \& Dienye, P. O. (2016). Determination of factors that influence job satisfaction among health workers in Southern Nigeria. Journal of Hospital Administration, 5(2). https://doi.org/10.5430/jha.v5n2p6

Keeton, K., Fenner, D. E., Johnson, T. R., \& Hayward, R. A. (2007). Predictors of physician career satisfaction, work-life balance, and burnout. Obstet Gynecol., 109(4), 949-55. PMID: 17400859. https://doi.org/10.1097/01.AOG.0000258299.45979.37

Khamlub, S., Harun-Or-Rashid, M, Sarker, M. A., Hirosawa, T., Outavong, P., \& Sakamoto, J. (2013). Job satisfaction of health-care workers at health centres in Vientiane Capital and Bolikhamsai Province, Lao PDR. Nagoya J Med Sci., 75(3-4), 233-41. PMID: 24640179; PMCID: PMC4345678.

Kolo, E. (2018). Job satisfaction among healthcare workers in a tertiary centre in Kano, Northwestern Nigeria. Niger J Basic Clin Sci., 15, 87-91. https://doi.org/10.4103/njbcs.njbcs_31_17

Liu, J. A., Wang, Q., \& Lu, Z. X. (2010). Job satisfaction and its modelling among township health center employees: a quantitative study in poor rural China. BMC Health Serv Res., 10(10), 115. PMID: 20459725; PMCID: PMC2907754. https://doi.org/10.1186/1472-6963-10-115

Measuring Job Satisfaction - Tools, Scales, Methods, Questionnaire. Retrieved 2019, Mar 8, from https://iedunote.com/measuring-job-satisfaction

Merga, H., \& Fufa, T. (2019). Impacts of the working environment and benefits packages on the health professionals' job satisfaction in selected public health facilities in eastern Ethiopia: using principal component analysis. BMC Health Serv Res, 19, 494. https://doi.org/10.1186/s12913-019-4317-5

Mengistu, M. M., \& Bali, A. G. (2015). Factors Associated to Job Satisfaction Among Healthcare Workers at Public Hospitals of West Shoa Zone, Oromia Regional State, Ethiopia: A Cross-Sectional Study. Science 
Journal of Public Health, 3(2), 161-167. https://doi.org/10.11648/j.sjph.20150302.12

Murawski, M. M., Payakachat, N., \& Koh-Knox, C. (2003). Factors affecting job and career satisfaction among community pharmacists: a structural equation modelling approach. $J$ Am Pharm Assoc, 48(5), 610-20. PMID: 18826900. https://doi.org/10.1331/JAPhA.2008.07083

Ofili, A. N., Asuzu, M. C., Isah, E. C., \& Ogbeide, O. (2004). Job satisfaction and psychological health of doctors at the University of Benin Teaching Hospital. Occupational Medicine, 1, 54(6), 400-403. https://doi.org/10.1093/occmed/kqh081

Okaro, O. A., Eze, C. U., \& Ohagwu, C. C. (2010). Survey of job satisfaction among Nigerian radiographers in south-eastern Nigeria. Euro J Sci Res, 39, 448-56. Retrieved from http://www.eurojournals.com/ejsr.htm

Omolase, C., Seidu, M., Omolase, B., \& Agborubere, D. (2010). Job satisfaction amongst Nigerian ophthalmologists: an exploratory study. Libyan J Med., 5(1), 4629. https://doi.org/10.3402/ljm.v5i0.4629

Pathman, D. E., Konrad, T. R., Williams, E. S., Scheckler, W. E., Linzer, M., \& Douglas, J. (2002). Career Satisfaction Study Group. Physician job satisfaction, dissatisfaction, and turnover. J Fam Pract., 51(7), 593. PMID: 12160487.

Pindar, S. K., Wakil, M. A., Coker, A. O., \& Abdul, I. W. (2015). Depression amongst healthcare workers in Maiduguri, north-eastern Nigeria. Research Journal of Health Sciences, 3(1), 21-30.

Samson-Akpan, P. E., Edet, O. B, Neji, O. I., \& Frank, A. E. (2015). Job Satisfaction among Nurses in Public Hospitals in Calabar, Cross River State Nigeria. American Journal of Nursing Science, 4(4), 231-237. https://doi.org/10.11648/j.ajns.20150404.22

Scanlan, L. M., Devine, S. G., \& Watkins, D. L. (2019). Job satisfaction of mental healthcare workers in multidisciplinary teams. $J$ Ment Health, 26, 1-8. PMID: 31347425. https://doi.org/10.1080/09638237.2019.1644489

Sieleunou, I. (2011). Health worker migration and universal health care in Sub-Saharan Africa. Pan Afr Med J, 10, 55. PMID: 22384301; PMCID: PMC3290885.

Singh, T., Kaur, M., Verma, M., \& Kumar, R. (2019). Job satisfaction among health care providers: A cross-sectional study in public health facilities of Punjab, India. J Family Med Prim Care, 8(10), 3268-75. https://doi.org/10.4103/jfmpc.jfmpc_600_19

Thompson, E. R., \& Phua, F. T. (2012). A brief index of affective job satisfaction. Group \& Organization Management, 37(3), 275-307. https://doi.org/10.1177/1059601111434201

World Health Organization. (2014). Global health workforce shortage to reach 12.9 million in coming decades WHO. World Health Organization; 2014.

Yakasai, I. A., Ugwa, E. A., \& Abubakar, I. S. (2013). Job satisfaction among resident doctors in a tertiary healthcare facility in Northern Nigeria, a cross-sectional. Tropical Journal of Obstetrics and Gynaecology, 30(1). https://www.ajol.info/index.php/tjog/article/view/99809

Yami, A., Hamza, L., Hassen, A, Jira, C., \& Sudhakar, M. (2011). Job satisfaction and its determinants among health workers in Jimma university specialized hospital, southwest Ethiopia. Ethiop J Health Sci., 21(Suppl 1), 19-27. PMID: 22435005; PMCID: PMC3275875.

Zhu, Y. A. (2013). Review of job satisfaction. Asian Social Science, 9(1), 293. https://doi.org/10.5539/ass.v9n1p293

Zuger, A. (2004). Dissatisfaction with Medical Practice. $N$ Engl $J$ Med, 350(1), 69-75. https://doi.org/10.1056/NEJMsr031703

\section{Copyrights}

Copyright for this article is retained by the author(s), with first publication rights granted to the journal.

This is an open-access article distributed under the terms and conditions of the Creative Commons Attribution license (http://creativecommons.org/licenses/by/4.0/). 